\begin{tabular}{r|l|l}
$\begin{array}{r}\text { Management } \\
2016 \\
\text { Vol. 20, No.1 }\end{array}$ & DE & $\begin{array}{l}\text { DE GRUYTER } \\
\text { OPEN }\end{array}$ \\
ISSN 1429-9321 & $\mathbf{G}$ & $\begin{array}{l}\text { DOI: } \\
10.1515 / \text { manment-2015-0045 }\end{array}$
\end{tabular}

MAŁGORZATA MATYJA

\title{
Resources based factors of competitiveness of agricultural enterprises
}

\section{Introduction}

A term of "competitiveness" is difficult to define. Its unclearness and ambiguity is the main problem to explain for the researchers in this field (Aniśkowicz 2013, p. 56). According to neoclassical economics the competitiveness is determined within the framework of microeconomic theory of prices on a perfectly competitive market, the marketing theory examines the competitiveness from the consumer's point of view of the consumer, and in strategic management competitiveness is explained close to the concept of economic efficiency (Chmielak 2004, p. 11). Even the scope of competitiveness is very wide - it can be considered from the following levels: global (mega scale), country (macro scale), sector (mezzo scale) and enterprise (micro scale) (Gardocka-Jałowiec 2007, p. 173). It is just the last level that is concerned in the article.

Speaking about competitiveness of an enterprise one can emphasize the importance of its products/services quality and prices (Brémond, Salort 1994), effective implementation of business objectives (Stankiewicz 2005), providing value added for stakeholders (Dwyer, Kim 2003, pp. 369 -414), effective using of available resources (Urbanowska-Sojkin, Banaszyk et al. 2004) 
or being profitable (Lombana 2006, pp. 32-43). Moreover, the competitiveness can be divided into, so called, factorial and resulting (Lubiński, Michalski et al. 1995). Factorial competitiveness applies to the company's activities which lead to effective competition and building competitiveness in the long term, e.g. a rapid response to environmental changes or a skillful use of available resources. In turn, the resulting competitiveness is the result of competition and can be identified with, for example, the acquired market share or financial results. Industrial recognition of the company's competitiveness is equally important. For example, evaluating competitiveness of farms M. Wigier (2014, p. 88) took into account the resources of production factors, efficiency of their use, dynamic and direction of structural changes.

Competitiveness of an enterprise is often linked with its performance. In that way of thinking performance is a state of competitiveness of the enterprise which ensures sustainable presence on the market, generating future results that arise as a result of meeting strategic objectives (Bumbescu 2015, p. 42). The performance consists of the efficiency and effectiveness, with which the resources are consumed (effort) and the results are generated (effects) in order to ensure the development of the organization's sphere of interest.

On the background of the above approaches to competitiveness for the purposes of this article the following definition of this term is used: competitiveness is the ability to be profitable by effective use of available resources. The next problematic issue that arises is finding the appropriate instruments for the operationalization of competitiveness (Bris, Caballero 2015, p. 492). According to the adopted definition the good measures of competitiveness can be the profitability ratios. These ratios are used to evaluate a business's ability to generate earnings compared to its expenses incurred during a period of time (Machek 2014, p. 61). They show the ability of the company to generate profit and are used by the company, financing institutions, etc. to determine the performance of the company (Berzkalne, Zelgalve 2014, p. 94). Some even think, that they are the indicators of assessing the firm's growth, success and control (Kabajeh, Al Nu'aimat, Dahmash 2012, p. 115). In agriculture the level of profitability is the synthetic indicator of financial standing, which fundamentally affects the assessment of the competitive abilities, which in turn influence the possibility of continuation of agricultural production and development perspectives (Gołaś 2009, p. 64).

However, it is worth noting, that given the importance of the profitability, the components of competitiveness should be better investigated (Korom, Sagi 2005 , p. 377). There is no consensus in theories regarding the definition and 
measurement of competitiveness - either in general, or specifically in agriculture where competitiveness is seriously determined by the input prices and by the subsidies (Bureau, Butault 1992, p. 30).

Aside of these problem the next important issue is to find out what can affect the competitiveness of agricultural enterprises. Identifying the factors that influence competitiveness is imperative in order to appreciate the position of the firm in relation to its environment and to propose appropriate measures and strategies for increasing competitiveness of agribusiness firms (Kirsten, Masuku 2014, p. 62). A related study conducted by D. Esterhuizen (2006, pp. 216 - 217) focused on factors constraining and enhancing the competitiveness of agribusinesses. The most important of the first group were: cost of crime, trust in the political systems and low level of competency of personnel working in public sector. The second group included: intensity of competition in the local market, availability of unskilled labour and production of affordable high quality products. P.L.R. Kennedy, N.G. Harrison and M.A. Piedra (1997, p. 245) found that agricultural enterprises were more competitive through cost leadership and/or product differentiation. Among sources of competitiveness they indicated: technology, input costs, production economics, product quality and enterprise differentiation, advertising, promotion and external factors. Z. Wysokińska (2001) linked competitiveness to efficient use of resources of production factors, as well as structural changes taking place in the economy resulting in increased efficiency of farming. K. Meredyk (2001) claimed that competitiveness is a feature of economic growth and follows directly from the quantity and quality of labour. Also A. Czyżewski and K. Smędzik-Ambroży (2015, p. 117) listed absorbency of labour, as well as absorbency of assets, as basic indicators of effectiveness of agricultural sector.

Given the above brief literature review, there are many factors which influence competitiveness of agricultural enterprises. They can be divided into different categories. One of them includes resources based factors. Traditionally in agriculture resources are linked with production factors such as: land, labor and capital (Harris, Codur 2004, p. 2). The interesting question is: which of the resources really affect agribusinesses' competitiveness and how strong is this impact? To address this, the purpose of this paper is to examine the relationship between selected resourced based factors and competitiveness of agricultural enterprises. The study is done on the basis of statistical data on selected Polish companies operating in agriculture. 


\section{Material and methods}

The present study utilizes a sampling frame consisting of agricultural entities from the "List of the 300 best agricultural enterprises", also known as "300 ranking" or "300 list", prepared annually by Instytut Ekonomiki Rolnictwa i Gospodarki Żywnościowej - Państwowy Instytut Badawczy (Institute of Agricultural and Food Economics - the National Research Institute in Poland) (IAFE 2010, IAFE 2011, IAFE 2012, IAFE 2013). The list includes agricultural enterprises established from the property of the Treasury (former state farms) and agricultural production cooperatives. The source data are collected using a specially designed questionnaire, which is aligned with the official items of financial statements.

The study analyzes the following types of agricultural enterprises:

- agricultural production cooperatives - APC,

- companies of state agency (Agricultural Property Agency) - CSA,

- private companies - PC,

- the rest of the entities - RE.

The time range of this study covers the years 2010 - 2013. The analysis is made of the sample of almost 300 entities in every year. It does not include over a dozen individual farms from the "300 list". Besides, in every year several agricultural enterprises from the "300 list" were not taken to the analysis because of the data inconsistencies. The detailed data on the size of the research sample are presented in table 1 .

Table 1. The number and percentage of enterprises in the research sample in every analyzed year

\begin{tabular}{c|c|c|c|c|c|c|c|c|c}
\hline \multirow{2}{*}{$\begin{array}{c}\text { Type of } \\
\text { enterprise }\end{array}$} & \multicolumn{2}{|c|}{2010} & \multicolumn{2}{c|}{2011} & \multicolumn{2}{c|}{2012} & \multicolumn{2}{c|}{2013} & $\begin{array}{c}\text { Average } \\
\%\end{array}$ \\
\cline { 2 - 11 } & Number & $\%$ & Number & $\%$ & Number & $\%$ & Number & $\%$ & 31 \\
\hline APC & 79 & 28 & 88 & 31 & 86 & 31 & 95 & 35 & 31 \\
\hline CSA & 9 & 3 & 41 & 15 & 38 & 14 & 36 & 13 & 11 \\
\hline PC & 150 & 54 & 138 & 49 & 140 & 50 & 130 & 47 & 50 \\
\hline RE & 40 & 14 & 15 & 5 & 17 & 6 & 14 & 5 & 8 \\
\hline Total & 278 & 100 & 282 & 100 & 281 & 100 & 275 & 100 & 100 \\
\hline
\end{tabular}

Source: own study 
The detailed data on the characteristics of enterprises in the research sample are presented in table 2 . The main characteristics of analyzed enterprises are very varied. The presented statistics (min, mean, max, standard deviation) show that there are huge differences between these entities in terms of their competitiveness (profitability ratios) and resources.

Table 2. Detailed characteristics of enterprises in the research sample

\begin{tabular}{|c|c|c|c|c|c|c|c|c|c|}
\hline Year & Statistic & $\begin{array}{c}\text { Hired } \\
\text { persons }\end{array}$ & $\begin{array}{l}\text { Agricul- } \\
\text { tural land } \\
\text { [ha] }\end{array}$ & $\begin{array}{l}\text { Boni- } \\
\text { tation } \\
\text { index }\end{array}$ & $\begin{array}{l}\text { Assets } \\
\text { [PLN] }\end{array}$ & ROS & ROA & ROE & VI \\
\hline \multirow{4}{*}{2010} & $\min$ & 1 & 97 & 0,24 & 10270 & $-115,1$ & $-7,7$ & $-14,3$ & $-2,4$ \\
\hline & mean & 39 & 1107 & 1,08 & 1503372 & $-9,7$ & 8,0 & 12,8 & 2,8 \\
\hline & $\max$ & 479 & 14232 & 1,76 & 39697826 & 43,8 & 43,5 & 209,7 & 14,2 \\
\hline & st. deviation & 57 & 1419 & 0,30 & 3046436 & 17,3 & 7,0 & 16,7 & 2,6 \\
\hline \multirow{4}{*}{2011} & $\min$ & 1 & 49 & 0,24 & 35800 & $-92,4$ & $-3,5$ & $-3,9$ & $-0,7$ \\
\hline & mean & 38 & 1087 & 1,09 & 1694853 & $-5,3$ & 9,8 & 16,2 & 2,5 \\
\hline & $\max$ & 508 & 13979 & 1,72 & 56208611 & 32,1 & 60,2 & 344,9 & 59,8 \\
\hline & st. deviation & 56 & 1383 & 0,29 & 3850231 & 17,4 & 8,6 & 28,2 & 3,9 \\
\hline \multirow{4}{*}{2012} & $\min$ & 2 & 55 & 0,24 & 5547 & $-174,0$ & $-1,9$ & $-2,8$ & $-0,6$ \\
\hline & mean & 37 & 1062 & 1,09 & 1935825 & 0,4 & 11,8 & 17,0 & 3,1 \\
\hline & $\max$ & 522 & 13824 & 1,69 & 60501113 & 38,0 & 45,8 & 128,1 & 27,3 \\
\hline & st. deviation & 56 & 1388 & 0,29 & 5164080 & 18,6 & 8,6 & 14,0 & 2,6 \\
\hline \multirow{4}{*}{2013} & $\min$ & 1 & 35 & 0,32 & 58627 & $-91,3$ & $-3,3$ & $-8,1$ & $-1,9$ \\
\hline & mean & 37 & 1025 & 1,07 & 1911145 & $-7,5$ & 5,6 & 8,5 & 2,1 \\
\hline & $\max$ & 571 & 14129 & 1,69 & 62279235 & 34,5 & 32,2 & 219,7 & 10,8 \\
\hline & st. deviation & 61 & 1405 & 0,30 & 4364208 & 13,8 & 5,3 & 14,7 & 1,9 \\
\hline \multirow{3}{*}{$\begin{array}{l}2010- \\
2013\end{array}$} & mean & 38 & 1070 & 1,08 & 1761299 & $-5,5$ & 8,8 & 13,6 & 2,6 \\
\hline & st. deviation & 1 & 35 & 0,01 & 203187 & 4,3 & 2,6 & 3,9 & 0,4 \\
\hline & \begin{tabular}{|}
$\mid$ st.devia- \\
tion/ mean $\mid$
\end{tabular} & $3 \%$ & $3 \%$ & $1 \%$ & $12 \%$ & $79 \%$ & $30 \%$ & $28 \%$ & $16 \%$ \\
\hline
\end{tabular}

Source: own study 
In years 2010-2013 the analyzed enterprises hired on average 38 people, cultivated over 1000 ha of agricultural land of good quality (the average bonitation index was approximately 1,1) and increased assets from $1,5 \mathrm{mln}$ to almost $2 \mathrm{mln}$ PLN. They achieved differentiated average profitability ratios: ROS from $-9,7$ to $0,4, \mathrm{ROA}$ from 5,6 to $11,8, \mathrm{ROE}$ from 8,5 to 17 and value index (VI) from 2,1 to 3,1 . An interesting observation is that the level of competitiveness measured by profitability ratios varied from year to year while the values of resources remained relatively constant. This finding is confirmed by the data presented at the bottom of the table 2 and graphically in figure 1.

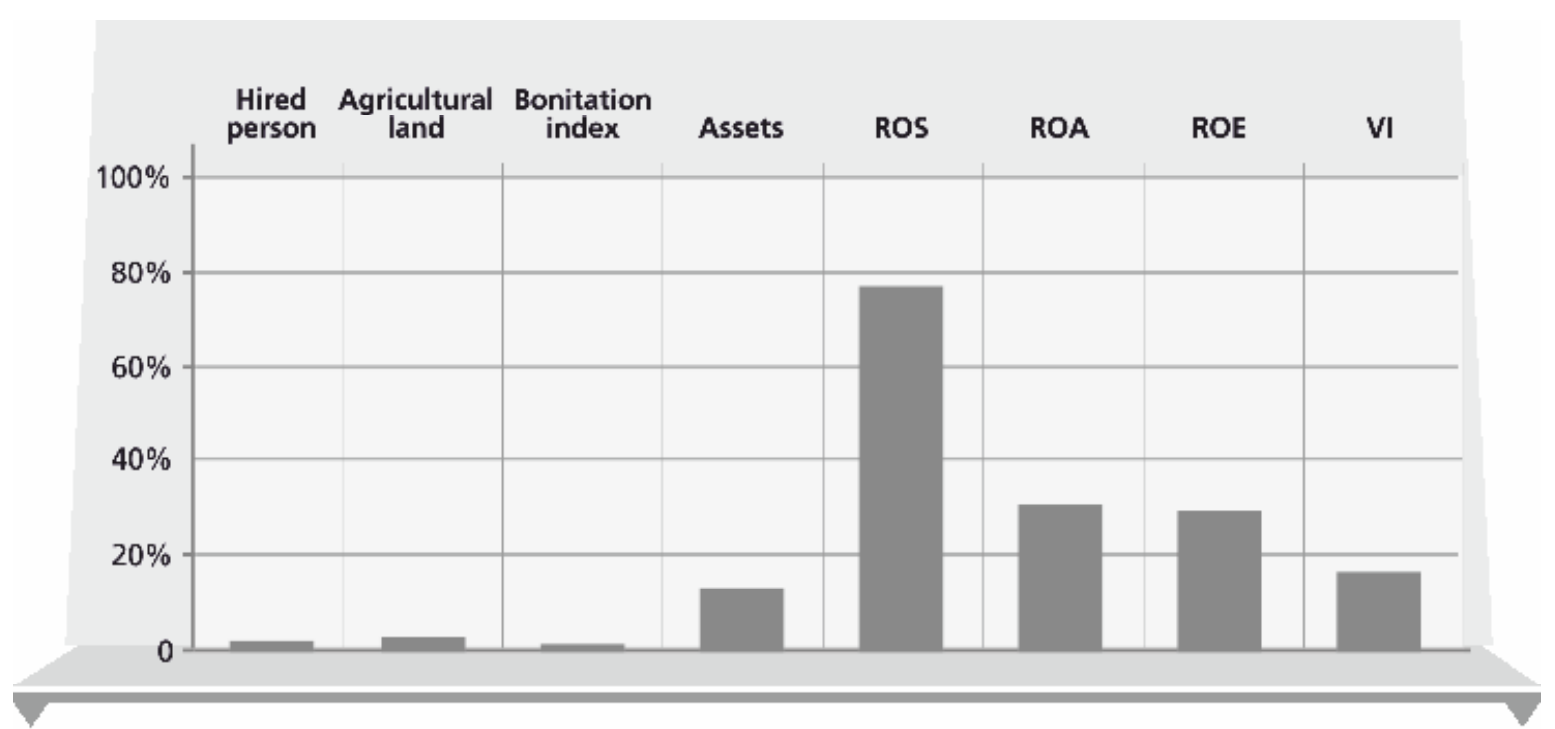

Figure 1 . The percentage expression of data variability in years 2010-2013

Source: own study

To add insight to the understanding how the competitiveness in Polish agricultural enterprises looks like, the author proposes a set of four hypotheses. They are designed to assess if the selected resource based factors have an impact on competitiveness of agricultural enterprises. The hypotheses are the following: $\mathrm{H}_{\mathrm{A}}$ : There is a correlation between the level of employment and competitiveness in agricultural enterprises.

$\mathrm{H}_{\mathrm{B}}$ : There is a correlation between the size of agricultural land and competitiveness in agricultural enterprises.

$\mathrm{H}_{\mathrm{C}}$ : There is a correlation between the bonitation index and competitiveness in agricultural enterprises. 
$\mathrm{H}_{\mathrm{D}}$ : There is a correlation between the size of assets and competitiveness in agricultural enterprises.

The competitiveness in this study consists of four components (IAFE 2010, IAFE 2011, IAFE 2012, IAFE 2013):

- return on sales (ROS) - the ratio of profit on sales to the sum of revenues from sales of products, goods and materials. The operating costs, calculated in the profit on sales, include also the labor costs of member-workers of agricultural production cooperatives,

- return on assets (ROA) - the ratio of net financial profit, adjusted for profit (-) or losses (+) from the disposal of non-financial assets, to the value of general assets at the end of a year,

- return on equity (ROE) - the ratio of net financial profit, adjusted for profit (-) or losses (+) from the disposal of non-financial assets, to capital equity at the end of a year,

- value index (VI) - the ratio of return on equity and the cost of capital equity containing, among others, an average interest rates on bank deposits; only index higher than one means that the value of the enterprise was increased for its owners.

The level of employment is measured as an average number of employees in every year, including worker-members working in cooperatives. The size of agricultural land means the area of land designated for agricultural activity. It includes arable land, permanent grassland and permanent plantations. The bonitation index is a synthetic measure of the quality of agricultural land calculated as the ratio of the conversion surface to the physical surface of the agricultural land. The size of assets includes the value of general assets indicated in balance sheet.

The data analysis was done in STATISTICA software. In order to accomplish the objectives of research and verify hypotheses the correlation analysis was used. Because all the variables were not normally distributed there was a need to use the non-parametric methods of correlation analysis. This type of analysis is used to accurately determine the degree to which two variables are related. The following formula of statistical hypotheses was adopted (Stanisz 2006, p. 197):

- null hypothesis $H_{0}$ : there is a lack of correlation between variables;

- alternative hypothesis $H_{i}$ : there is a correlation between variables.

The process of verifying hypotheses consisted in rejecting the null hypothesis in favor of the adoption of its alternative. The correlation was statistically significant with the $p$-value lower than $\alpha=0.05$. The correlation analysis used in this study was based on the calculation and interpretation of Spearman's 
rank coefficient. This coefficient takes values from the range of $\leq-1,1 \geq$. Minus coefficient indicated the negative correlation. The higher the absolute value of the coefficient was, the stronger was the correlation between the variables. Particularly, a scale for evaluating the strength of the correlation between variables was the following (Stanisz 2006, p. 293):

- correlation coefficient $=0$ - variables are not correlated,

- $0<$ correlation coefficient $<|0,1|$ - correlation very weak,

- $|0,1| \leq$ correlation coefficient $<|0,3|$ - correlation weak,

- $|0,3| \leq$ correlation coefficient $<|0,5|$ - correlation average,

- $|0,5| \leq$ correlation coefficient $<|0,7|$ - correlation high,

- $|0,7| \leq$ correlation coefficient $<|0,9|$ - correlation very high,

- $|0,9| \leq$ correlation coefficient $<|1|$ - correlation almost full.

\section{Results}

To sum up, the Spearman's rank correlation was conducted to determine if and how the selected resources based factors (employment, the size and quality of agricultural land and the size of assets) were associated with the competitiveness of agricultural enterprises (measured by ROS, ROA, ROE and VI). The values of correlation coefficients are presented in table 3 . The presence of a correlation between particular variables is highlighted in bold font.

Table 3. The correlation between resources based factors and competitiveness of agricultural enterprises in years 2010- 2013

\begin{tabular}{l|c|c|c|c|c|c|c|c}
\hline & \multicolumn{2}{|c|}{2010} & \multicolumn{2}{c|}{2011} & \multicolumn{2}{c}{2012} & \multicolumn{2}{c}{2013} \\
\cline { 2 - 9 } & $\begin{array}{c}\mathbf{R} \\
\text { Spearman }\end{array}$ & $\mathbf{p}$ & $\begin{array}{c}\mathbf{R} \\
\text { Spearman }\end{array}$ & $\mathbf{p}$ & $\begin{array}{c}\mathbf{R} \\
\text { Spearman }\end{array}$ & $\mathbf{p}$ & $\begin{array}{c}\mathbf{R} \\
\text { Spearman }\end{array}$ & $\mathbf{p}$ \\
\hline $\begin{array}{l}\text { Employment \& } \\
\text { ROS }\end{array}$ & 0,0 & 0,85 & $-0,1$ & 0,23 & $-\mathbf{0 , 1}$ & $\mathbf{0 , 0 4}$ & $\mathbf{0 , 2}$ & $\mathbf{0 , 0 1}$ \\
\hline $\begin{array}{l}\text { Employment \& } \\
\text { ROA }\end{array}$ & $-\mathbf{0 , 3}$ & $\mathbf{0 , 0 0}$ & $-\mathbf{0 , 3}$ & $\mathbf{0 , 0 0}$ & $-\mathbf{0 , 3}$ & $\mathbf{0 , 0 0}$ & $-0,1$ & 0,11 \\
\hline $\begin{array}{l}\text { Employment \& } \\
\text { ROE }\end{array}$ & $-\mathbf{0 , 4}$ & $\mathbf{0 , 0 0}$ & $-\mathbf{0 , 3}$ & $\mathbf{0 , 0 0}$ & $-\mathbf{0 , 3}$ & $\mathbf{0 , 0 0}$ & $-\mathbf{0 , 1}$ & $\mathbf{0 , 0 4}$ \\
\hline $\begin{array}{l}\text { Employment } \\
\text { \& VI }\end{array}$ & $-\mathbf{0 , 4}$ & $\mathbf{0 , 0 0}$ & $-\mathbf{0 , 3}$ & $\mathbf{0 , 0 0}$ & $-\mathbf{0 , 3}$ & $\mathbf{0 , 0 0}$ & $-0,1$ & 0,05 \\
$\ldots-.-\cdots$
\end{tabular}




\begin{tabular}{l|c|c|c|c|c|c|c|c}
\hline $\begin{array}{l}\text { Agricultural } \\
\text { land \& ROS }\end{array}$ & 0,1 & 0,31 & 0,0 & 0,80 & 0,1 & 0,21 & $\mathbf{0 , 2}$ & $\mathbf{0 , 0 1}$ \\
\hline $\begin{array}{l}\text { Agricultural } \\
\text { land \& ROA }\end{array}$ & 0,0 & 0,48 & 0,0 & 0,88 & 0,0 & 0,90 & 0,1 & 0,10 \\
\hline $\begin{array}{l}\text { Agricultural } \\
\text { land \& ROE }\end{array}$ & 0,0 & 0,42 & 0,0 & 0,89 & 0,0 & 0,96 & 0,1 & 0,40 \\
\hline $\begin{array}{l}\text { Agricultural } \\
\text { land \& VI }\end{array}$ & 0,0 & 0,50 & 0,0 & 0,89 & 0,0 & 0,86 & 0,1 & 0,26 \\
\hline $\begin{array}{l}\text { Bonitation index } \\
\text { \& ROS }\end{array}$ & $\mathbf{0 , 2}$ & $\mathbf{0 , 0 1}$ & $\mathbf{0 , 3}$ & $\mathbf{0 , 0 0}$ & $\mathbf{0 , 2}$ & $\mathbf{0 , 0 0}$ & 0,1 & 0,09 \\
\hline $\begin{array}{l}\text { Bonitation index } \\
\text { \& ROA }\end{array}$ & 0,0 & 0,60 & 0,1 & 0,13 & 0,0 & 0,80 & 0,0 & 0,83 \\
\hline $\begin{array}{l}\text { Bonitation index } \\
\text { \& ROE }\end{array}$ & $-0,1$ & 0,37 & 0,1 & 0,25 & 0,0 & 0,97 & 0,0 & 0,89 \\
\hline $\begin{array}{l}\text { Bonitation index } \\
\text { \& VI }\end{array}$ & 0,0 & 0,42 & 0,1 & 0,13 & 0,0 & 0,95 & 0,0 & 0,92 \\
\hline Assets \& ROS & $\mathbf{0 , 2}$ & $\mathbf{0 , 0 0}$ & $\mathbf{0 , 2}$ & $\mathbf{0 , 0 0}$ & $\mathbf{0 , 2}$ & $\mathbf{0 , 0 0}$ & $\mathbf{0 , 3}$ & $\mathbf{0 , 0 0}$ \\
\hline Assets \& ROA & $\mathbf{- 0 , 3}$ & $\mathbf{0 , 0 0}$ & $\mathbf{- 0 , 2}$ & $\mathbf{0 , 0 0}$ & $\mathbf{- 0 , 2}$ & $\mathbf{0 , 0 0}$ & 0,0 & 0,80 \\
\hline Assets \& ROE & $\mathbf{- 0 , 3}$ & $\mathbf{0 , 0 0}$ & $\mathbf{- 0 , 2}$ & $\mathbf{0 , 0 0}$ & $\mathbf{- 0 , 2}$ & $\mathbf{0 , 0 0}$ & 0,0 & 0,88 \\
\hline Assets \& VI & $\mathbf{- 0 , 3}$ & $\mathbf{0 , 0 0}$ & $\mathbf{- 0 , 2}$ & $\mathbf{0 , 0 0}$ & $\mathbf{- 0 , 2}$ & $\mathbf{0 , 0 0}$ & 0,0 & 0,86 \\
\hline RO,
\end{tabular}

Source: own study

The main findings from the correlation analysis are in part quite obvious, and in part surprising. Their interpretation is presented below.

The level of employment is found to be significantly, negatively and mostly weakly correlated with ROA (except of year 2013), ROE and VI (except of year 2013). This seems to be explainable because the more people are hired, the higher are the salary costs and the lower is the profit which is attributable to a relatively constant value of assets or equity. The different situation is in the case of ROS. This indicator divides the profit between revenues from sales which can vary seriously from year to year due to the impact of weather conditions on the value of sale. This might be simply the consequence of fluctuations in prices of agricultural products. 
The bonitation index is found to be significantly, positively and weakly correlated with ROS (except of year 2013). The higher quality of agricultural land is, the higher are both: the revenues and the profit with relatively constant cost of sales. However, the analysis has shown that the higher quality of agricultural land has nothing in common with the increase or decrease of ROA, ROE or VI.

The assets are found to be significantly, positively and weakly correlated with ROS. This relationship might be a result of keeping and selling from current assets, especially inventories.

The assets are found to be significantly, negatively and weakly correlated with ROA, ROE, VI (except of year 2013). The analysis confirmed that the larger size of assets the agricultural enterprises have, the less is the return on assets and equity, and as a consequence the lower is the value index. The value of assets and equity in agricultural sector is usually very high and achieved gains are disproportionate. Greater assets means more problems with their control.

The size of agricultural land is found to be not correlated with ROS, ROA, ROE and VI. This finding seems to be the most surprising. It turns out that no matter how big land is cultivated in the context of agricultural enterprises' competitiveness. It means, more or less, that small companies, with relatively small agricultural land, can achieve the same or even higher profitability ratios as the big ones, and vice versa. The size of agricultural land does not influence the enterprise profitability.

\section{Conclusions}

Some important conclusions can be drawn in the light of a brief literature review and the results of the analysis made in this paper. Firstly, the profitability ratios such as ROS, ROE, ROA or VI seem to be insufficient measures of company's competitiveness. They show only the part of enterprise's financial side and do not include other important aspects of its achievements. Additionally, in some cases they are not good measures of company's performance at all. This applies mainly to cooperatives which are not-profit oriented enterprises as their major goal is to provide benefits to their members and local community. In this area, therefore, it is worth to analyze the impact of various factors of production also on other elements of competitiveness, such as the price of sold products, their quality, the ability to penetrate the market, the ability to achieve business goals, etc.

Secondly, the correlation analysis proved that there is a relatively small relationship between main resources based factors and competitiveness (or 
more precisely - profitability) of agricultural enterprises. It was also confirmed by fig. 1. which showed a relatively constant level of analyzed resources in every year compared to large variability of profitability ratios. This observation means that other factors have stronger impact on company's competitiveness. They can probably refer to intangible resources (such as relational capital, know-how, managerial competencies, technological resources etc.) and external conditions (such as climate, legal issues) of agricultural enterprises. However, it should be also noted that in the short term (the time range of the study are four years) the profitability of agricultural enterprises is determined mainly by agricultural commodity prices and operating costs. This relationship usually becomes less important in the long term, and a greater role can play just resource factors. This research problem should therefore be examined also in a broader time horizon.

Thirdly, it is also worth to look at the analysis of the competitiveness of agricultural enterprises from the side of orientation of their production. There may be some correlation between available resources of land, labor and capital and the structure of production. This in turn may be related to the competitiveness of agribusiness entities.

Lastly, the paper points out the huge differences in terms of competitiveness/ profitability of companies operating in agriculture. Therefore, they need to be examined more deeply. Finding out what makes them perform better or worse seems to be not only scientifically justified but also interesting in the objective point of view.

\section{Summary}

\section{Resourced based factors of competitiveness of agricultural enterprises}

Among many different definitions of competitiveness it is difficult to pinpoint the most appropriate one. In the paper it was defined as the ability to be profitable by effective use of available resources. The profitability ratios (ROS, ROA, ROE and value index) were proposed as measures of competitiveness and resources were indicated as one of the group of factors that has an impact on it. Precisely, the purpose of the paper was to examine the relationship between selected resourced based factors and competitiveness of agricultural enterprises. The study was done with the use of correlation analysis on the basis of statistical data on selected Polish companies operating in agriculture. The main finding was

Resources based factors of competitiveness

of agricultural enterprises 
that the analyzed resources (the level of labour, size and quality of agricultural land and size of assets) were weakly correlated with competitiveness. This observation means that other factors have stronger impact on agricultural company's competitiveness. They can refer to intangible resources (such as relational capital, knowhow, managerial competencies, technological resources etc.) and external conditions (such as climate, legal issues) of agricultural enterprises.

Keywords: competitiveness, resources, agricultural enterprises, profitability, correlation.

\section{Streszczenie}

\section{Zasobowe czynniki konkurencyjności przedsiębiorstw rolnych}

Spośród wielu różnych definicji konkurencyjność trudno jest wskazać tą najwłaściwszą. W artykule zdefiniowano ją jako zdolność bycia rentownym na drodze efektywnego wykorzystania dostępnychzasobów.Jakomiarykonkurencyjnościzaproponowano wskaźniki rentowności (ROS, ROA, ROE i indeks wartości), a zasoby wskazano jako jedną z grup czynników ją kształtujących. Dokładniej, celem artykułu było zbadanie zależności pomiędzy wybranymi czynnikami zasobowymi a konkurencyjnością przedsiębiorstw rolnych. W badaniu wykorzystano analizę korelacji, wykonaną na statystycznych danych dotyczących wybranych polskich przedsiębiorstw działających w rolnictwie. Głównym wnioskiem było stwierdzenie, że analizowane zasoby (poziom zatrudnienia, wielkość i jakość użytków rolnych oraz wielkość posiadanego majątku) są słabo skorelowane z konkurencyjnością. Ta obserwacja oznacza, że inne czynniki mają większy wpływ na konkurencyjność przedsiębiorstw rolnych. Mogą one obejmować ich zasoby niematerialne (takie jak np. kapitał relacyjny, know-how, kompetencje menedżerskie, zasoby technologiczne) oraz ich uwarunkowania zewnętrzne (czynniki klimatyczne, kwestie prawne).

\section{Słowa}

kluczowe: $\quad$ konkurencyjność, zasoby, przedsiębiorstwa rolne, rentowność, korelacja. 


\section{References}

1. Aniśkowicz M. (2013), Konkurencyjnośćprzedsiębiorstww ujęciu teoretycznym, "Rozprawy naukowe $i$ zawodowe Państwowej Wyższej Szkoły Zawodowej w Elblagu", Vol. 16.

2. Berzkalne I., Zelgalve E. (2014), Return on equity and company characteristics: an empirical study of industries in Latvia, in: T. Löster, T. Pavelka (eds.), The 8th International Days of Statistics and Economics, Prague, September 11-13, 2014. Conference Proceedings, Libuse Mackova, Melandrium, Slaný.

3. Brémond J., Salort M.M. (1994), Odkrywanie ekonomii, Wydawnictwo Naukowe PWN, Warszawa.

4. Bris A., Caballero J. (2015), Revisiting the Fundamentals of Competitiveness: A Proposal, in: IMD World Competitiveness Yearbook, IMD World Competitiveness Center, Lausanne.

5. Bumbescu S. S. (2015), Performance analysis in agriculture using Du Pont model, "Sibiu Alma Mater University Journals", Series A. Economic Sciences, Vol. 8, No. 2.

6. Bureau J. C., Butault J. P. (1992), Productivity gaps, price advantages and competitiveness in E. C. agriculture, "European Review of Agricultural Economics", Vol. 19, No. 1.

7. Chmielak A. (2004), Próba interpretacji konkurencyjności systemowej, [in:] J. Szabłowski (ed.), Strategie konkurencji przedsiębiorstw - wybrane zagadnienia, Wyższa Szkoła Finansów i Zarządzania w Białymstoku, Białystok.

8. Czyżewski A., Smędzik-Ambroży K. (2015), The efficiency of agricultural sector in Poland in light of output-input model, "Management", Vol. 19, No. 1.

9. Dwyer L., Kim Ch. (2003), Destination Competitiveness: Determinants and Indicators, "Current Issues in Tourism", Vol. 6, No. 5.

10. Esterhuizen D. (2006), An Evaluation of the Competitiveness of the South African Agribusiness Sector, University of Pretoria, http://repository. up.ac.za/bitstream/handle/2263 / 30241/Complete.pdf? sequence=9 (01.02.2016 - access date).

11. Gardocka-Jałowiec A. (2007), Kapitał społeczny jako deskryptor przewagi konkurencyjnej, in: T. Bernat (ed.), Przedsiębiorstwo i państwo - wybrane problemy konkurencyjności, Uniwersytet Szczeciński, Szczecin.

12. Gołaś Z. (2009), Analiza rentowności kapitału w rolnictwie, "Journal of Agribusiness and Rural Development", Vol. 1, No. 11.

13. Harris M., Codur A.M. (2004), Macroeconomics and the Environment, Tufts University Global Development And Environment Institute, Medford.

14. IAFE (2010), List of the 300 best agricultural enterprises, http:/ / www.ierigz. waw.pl/prace-badawcze/ranking-300/wyniki-2010 (20.01.2016 - access date).

15. IAFE (2011), List of the 300 best agricultural enterprises, http:/ / www.ierigz. 
waw.pl/prace-badawcze/ranking-300/wyniki-2011 (20.01.2016 - access date).

16. IAFE (2012), List of the 300 best agricultural enterprises, http://www.ierigz. waw.pl/prace-badawcze/ranking-300/wyniki-2012 (20.01.2016 - access date).

17. IAFE (2013), List of the 300 best agricultural enterprises, http:/ / www.ierigz. waw.pl/prace-badawcze/ranking-300/wyniki-2013 (20.01.2016 - access date).

18. Kabajeh M.A.M., Al Nu'aimat S.M.A., Dahmash F.N. (2012), The Relationship between the ROA, ROE and ROI Ratios with Jordanian Insurance Public Companies Market Share Prices, "International Journal of Humanities and Social Science", Vol. 2, No. 11.

19. Kennedy P.L.R.W., Harrison, N. G., Piedra M. A. (1998), Analyzing Agribusiness competitiveness: The case of the United States Sugar Industry, "International Food and Agribusiness Management Review", Vol. 1, No. 2.

20. Kirsten J. F., Masuku M. B. (2014), Factors Affecting the Competitiveness of the Agribusiness Sector in Swaziland, "Journal of Agricultural Studies", Vol. 2, No. 1.

21. Korom E., Sagi J. (2005), Measures of competitiveness in agriculture, "Journal of Central European Agriculture", Vol. 6., No. 3.

22. Lombana J. E. (2006), Competitiveness and Trade Policy Problems in Agricultural Export, University of Gotingen, Gotingen.

23. Lubiński M., Michalski T., Misala J. (1995), Międzynarodowa konkurencyjność gospodarki. Pojęcia $i$ sposób mierzenia, Instytut Rozwoju i Studiów Strategicznych, Warszawa.

24. Machek O. (2014), The relationship between financial performance and total factor productivity: evidence from the Czech agricultural sector, "International Journal Of Social Sciences And Humanity Studies", Vol. 6, No. 2.

25. Meredyk K. (2001), Przestanki wzrostu konkurencyjności gospodarki polskiej, in: J. Bossak, W. Bieńkowski (eds.), Konkurencyjność gospodarki Polski $w$ dobie integracji z UE i globalizacji, SGH, Warszawa.

26. Stanisz A. (2006), Przystęny kurs statystyki z zastosowaniem STATISTICA PL na przykładach z medycyny, Vol. 1., Statsoft Polska, Kraków.

27. Stankiewicz M. (2005), Konkurencyjność Przedsiębiorstwa. Budowanie konkurencyjności przedsiębiorstwa w warunkach globalizacji, Dom Organizatora, Torun.

28. Urbanowska-Sojkin E., Banaszyk H., Witczak H. (2004), Zarządzania strategiczne przedsiębiorstwem, PWE, Warszawa.

29. Wigier M. (2014), The competitiveness of Polish agriculture after accession to $E U$, "Economics of Agriculture", Vol. 1, No. 61.

30. Wysokińska Z. (2001), Konkurencyjność w międzynarodowym i globalnym handlu technologiami, Wydawnictwo Naukowe PWN, Warszawa. 